\title{
Meningkatkan Hasil Belajar PKn Materi Peran Indonesia di Dunia Internasional dengan Metode Problem Solving pada siswa Kelas VI SDN Monyel Tahun Pelajaran 2017/2018
}

\author{
SUARDI \\ Guru kelas SDN Monyel Kecamatan Pujut \\ Kabupaten Lombok Tengah
}

\begin{abstract}
Abstrak; Penelitian ini bertujuan untuk meningkatkan hasil belajar PKn pada siswa kelas VI SDN Monyel Tahun pelajaran 2017/2018 melalui penerapan metode problem solving. Penelitian ini merupakan penelitian tindakan kelas, menggunakan model Kemmis dan Mc Taggart. Subjek dalam penelitian ini adalah siswa kelas VI SDN Monyel Tahun Pelajaran 2017/2018 yang berjumlah 26 siswa, terdiri dari 10 siswa laki-laki dan 16 siswa perempuan. Teknik yang digunakan untuk pengumpulan data adalah dengan tes Teknik analisis data yang digunakan yaitu deskriptif kualitatif dan deskriptif kuantitatif. Metode Problem Solving yang peneliti terapkan di kelas VI SDN Monyel bertujuan untuk meningkatkan hasil belaajar siswa terhadap mata pelajaran PKn menunjukkan adanya persentase peningkatan Peningkatan hasil yang dicapai tersebut dapat dilihat dari hasil tes pada setiap siklusnya. Berdasarkan hasil belajar pada tes awal perolehan nilai dibawah ketuntasan maksimal (KKM) PKn di SDN Monyel Tahun Pelajaran 2017/2018, yakni 70. Pada kenyataannya nilai peserta didik di bawah 70 , dari 26 orang yang tuntas belajar hanya 10 orang atau persentase ketuntasan sebesar 38,46\% dan siswa yang tidak tuntas 16 orang atau sebesar $61,53 \%$. Setelah diberikan tindakan maka perolehan hasil rata-rata nilai siswa meningkat dari siklus I sebesar 68,84 menjadi 90,38 pada siklus II, terjadi peningkatan sebesar 21,54 , dan ketuntasan belajar pada siklus I sebesar 57,69 \% meningkat pada siklus II menjadi 92,30 terjadi peningkatan sebesar 34,61 poin ,dengan demikian maka ketuntasan klasikalpun sudah tercapai sehingga penelitian ini dihentikan sampai pada siklus II. Dengan demikian dapat disimpulkan bahwa metode Problem Solving dapat meningkatkan hasil belajara siswa dalam pembelajaran PKn di kelas VI SDN Monyel.
\end{abstract}

\section{Kata kunci: Pembelajaran PKn, Problem Solving, hasil belajar}

\section{PENDAHULUAN}

Dalam dunia pendidikan, belajar merupakan kegiatan yang kompleks. Setelah belajar para siswa/peserta didik diharapkan akan adanya perubahan perilaku. Proses belajar terjadi karena adanya interaksi antara siswa dengan lingkungannya. Oleh karena itu lingkungan pendidikan perlu diatur sedemikian rupa sehingga timbul reaksi siswa ke arah perubahan tingkah laku yang diinginkan.

Salah satu hal yang memegang peranan penting bagi keberhasilan pembelajaran adalah proses pelaksanaan pembelajaran. Pelaksanaan pembelajaran yang baik sangat dipengaruhi oleh perencanaan yang baik pula. Pada prinsipnya, pembelajaran merupakan interaksi antara guru dengan siswa dalam proses belajar mengajar. Proses belajar mengajar merupakan dua entitas yang membentuk satu kesatuan, ibarat suatu koin mata uang yang berisi dua sisi berbeda yang tak dapat dipisahkan

Berdasarkan hasil ulangan harian kelas VI pada mata pelajaran PKn yang diikuti oleh 26 siswa,yang tuntas belajar hanya 10 orang atau persentase ketuntasan sebesar $38,46 \%$ kemudian siswa yang tidak tuntas belajar sebanyak 16 siswa atau persentase sebesar 61,53 \%. Dan KKM yang ditetapkan SDN Monyel untuk mata pelajaran $\mathrm{PKn}$ adalah 70 pada tahun pelajaran 2017/2018, dengan ketuntasan kelasikal $\geq 85 \%$. Rendahnya hasil belajar siswa disebabkan karena guru kurang bervariasi dalam menggunakan metode pembelajaran, tidak menggunakan media pembelajaran dan tidak melibatkan siswa secara aktif dalam proses pembelajaran.

Untuk mengatasi hal tersebut peneliti menawarkan untuk menggunakan metode Problem Solving, agar siswa aktif, 
mampu bekerjasama, saling menukar pengalaman, informasi, dan mampu memecahkan masalah, sehingga siswa memperoleh pembelajaran bermakna.Oleh karena itu, metode pembelajaran yang digunakan guru harus benar-benar memperhatikan karakteristik siswa sehingga dengan metode tersebut guru mampu memancing emosi siswa untuk aktif dalam proses pembelajaran.

Metode diskusi merupakan salah satu metode yang dapat menjadikan siswa aktif, mandiri, menyenangkan, dan mampu membentuk kerjasama yang baik antar guru dan siswa, antar siswa dengan siswa yang lain.

Dari uraian di atas merupakan gambaran betapa pentingnya menciptakan belajar siswa yang aktif dan menyenangkan. Penulis merasa tertarik untuk melakukan penelitian dengan judul“" Meningkatan Hasil Belajar PKn Materi Peran Indonesia di Era Globalisasi dengan Metode Problem Solving pada Siswa Kelas VI SDN Monyel Tahun Pelajaran 2017/2018.

\section{Rumusan Masalah}

Berdasarkan uraian di atas maka ,dapat disusun rumusan masalahnya “ Bagaimanakah Meningkatan Hasil Belajar PKn Materi Peran Indonesia di Era Globalisasi dengan Metode Problem Solving pada Siswa Kelas VI SDN Monyel Tahun Pelajaran 2017/2018?.

\section{Tujuan Penelitian}

Berdasarkan rumusan masalah tersebut, maka penelitian ini bertujuan untuk Meningkatan Hasil Belajar PKn Materi Peran Indonesia di Era Globalisasi dengan Metode Problem Solving pada Siswa Kelas VI SDN Monyel Tahun Pelajaran 2017/2018

\section{Manfaat Penelitian}

Hasil penelitian ini diharapkan dapat memberi manfaat, baik secara teoritis maupun secara praktis kepada berbagai pihak . secara teoritis manfaat penelitian ini untuk khazanah intelektual, diharapkan penelitian ini menjadi sebuah sumbangsih gagasan dan tawaran solusi terhadap persoalan pelaksanaan metode Problem Solving yang selama ini masih terjadi kontraversi.

$$
\text { Adapun Manfaat praktis }
$$

penelitian ini meliputi ;(1) dapat meningkatkan keaktifan baik fisik, intelektual, maupun emosional dan mengembangkan kreativitas dalam proses belajar PKn, sehingga siswa mendapatkan pengetahuan yang bermakna, (2) Dapat menciptakan lingkungan belajar yang memberi peluang kepada siswa untuk terlibat aktif dan menciptakan suasana belajar yang menyenangkan

\section{Landasan Teori Dan Kajian Pustaka Pembelajaran PKn}

Ada banyak pengertian yang diberikan oleh ahli Pendidikan dan teori belajar terhadap arti belajar itu sendiri. Hal demikian merupakan suatu yang wajar dalam perkembangan keilmuan, karena masingmasing dari mereka mempunyai metode, pendekatan, dan latar belakang yang berbeda, serta lingkungan sosio-kultural yang mengitarinya juga berbeda pula. Namun diantara mereka masih terdapat titik singgung atau titik temu mengenai apa belajar itu sendiri dan juga apa hakikat dari belajar.

Sedangkan Arief S. Sadiman, R. Rahardjo, Anung Haryono, dan Rahardjito mengartikan kata pembelajaran sengaja dipakai sebagai padanan kata dari kata bahasa Inggris instruction yang mempunyai pengertian lebih luas daripada pengajaran. Jika kata pengajaran ada dalam konteks gurumurid dikelas (ruang) formal, pembelajaran atau instruction mencakup kegiatan belajar mengajar yang dihadiri guru secara fisik. Oleh karena dalam instruction yang ditekankan adalah proses belajar, maka usahausaha yang terencana dalam memanipulasi sumber-sumber belajar agar terjadi proses belajar dalam diri siswa kita sebut pembelajaran(Arief S, dkk; 2010;7).

Menurut Udin Syaefudin Saud, kini mengajar lebih sering dimaknai sebagai perbuatan yang kompleks, yaitu penggunaan secara integrative sejumlah keterampilan untuk menyampaikan pesan (Udin ;2010;55).

Jadi dari pendapat - pendapat para ahli maka ditarik kesimpulan bahwa pembelajaran adalah suatu usaha yang sengaja melibatkan dan menggunakan pengetahuan professional yang dimiliki guru untuk mencapai tujuan kurikulum. Pembelajaran juga merupakan suatu aktifitas yang dengan sengaja untuk memodifikasi 
berbagai kondisi yang diarahkan untuk tercapainya suatu tujuan yaitu tercapainya tujuan kurikulum.

Setelah memahami definisi dari pembelajaran di atas, selanjutnya akan dipaparkan mengenai pengertian Pendidikan Kewarganegaraan dan Pembelajaran Pendidikan Kewarganegaraan. (UU No 20/2003 pasal 1 ayat 1) menyatakan: "Pendidikan adalah usaha sadar dan terencana untuk mewujudkan suasana belajar dan proses pembelajaran agar peserta didik secara akti mengembangkan potensi dirinya untuk memiliki kekuatan spiritual keagamaan, pengendalian diri, kepribadian, kecerdasan, akhlak mulia, serta keterampilan yang diperlukan dirinya, masyarakat, bangsa dan Negara".

Konsep pendidikan dalam era globalisasi tidak boleh terlepas dari pendidikan nilai (afektif), begitupun dengan aspek pengetahuan (kognitif), dan keterampilan (psikomor). Pendidikan tidak sekedar terfokus pada alih pengetahuan (transfer of knowledge), namun disertai pula signifikansi alih sikap (transfer of attitude). Hal ini seiring dengan pendapat Adimihardja bahwa fungsi pendidikan yang dibangun dan dikembangkan oleh suatu Negara adalah untuk meningkatkan peradaban ci $V$ lization anak bangsa, agar memiliki nilai- nilai budaya yang lebih tinggi. Melalui peningkatan peradaban, diharapkan manusia akan berprilaku lebih arif dalam memelihara keseimbangan hubungan antara sesama manusia, lingkungan di mana mereka hidup, dan terhadap Tuhan Yang Maha Esa(Ine Kusuma Aryani dkk 2010;10).

Menurut Muhammad Numan Somantri yang kutip A. Ubaedillah dan Abdul Rozak "bahwa Civic sebagai ilmu kewarganegaraan yang membicarakan hubungan manusia dengan: (a) manusia dalam perkumpulan-perkumpulan yang terorganisasi [organisasi social, ekonomi, politik]; (b) individu-individu dengan negara.

Sedang Azyumardi Azra yang dikutip A. Ubaedillah dan Abdul Rozak mengemukakan bahwa pendidikan Kewarganegaraan adalah pendidikan yang cakupannya lebih luas dari pendidikan demokrasi dan pendidikan HAM karena mencakup kajian dan pembahasan tentang banyak hal, seperti pemerintahan, konstitusi, lembaga- lembaga demokrasi, rule of law, hak dan kewajiban warga Negara, proses demokrasi, partisipasi aktif dan keterlibatan warga Negara dalam masyarakat madani, pengetahuan tentang lembaga-lembaga dan sistem yang terdapat dalam pemerintahan, politik, administrasi public dan sistem hukum, pengetahuan tentang HAM, kewarganegaraan aktif dan sebagainya(A. Ubaedillah, dkk 2008 ;7).

Berdasarkan pemaparan di atas dapat dikatakan bahwa kewarganegaraan merupakan salah satu pelajaran yang di dalamnya memuat berbagai nilai dan norma sendi-sendi kehidupan universal manusia baik individu, kelompok, bahkan masyarakat secara umum terhadap ilmu pengetahuan, teknologi, politik, ekonomi, sosial, budaya, dan agama.

Dan jika dilihat dari fungsinya, mata pelajaran PKn memiliki tiga misi besar. Pertama, misi conservation education, yakni, mengembangkan dan melestarikan nilai luhur Pancasila. Kedua, social and moral development, yakni, mengembangkan dan membina siswa yang sadar akan hak dan kewajibannya, taat pada peraturan yang berlaku, serta berbudi pekerti luhur. Dan ketiga, fungsi socio-civic development, yakni membina siswa agar memahami dan menyadari hubungan antar sesama anggota keluarga, sekolah, dan masyarakat, serta dalam kehidupan berbangsa dan bernegara.

Kewarganegaraan merupakan materi yang memfokuskan pada pembentukan diri yang beragam, baik dari segi agama, sosio cultural, usia, dan suku bangsa,untuk menjadi warga Negara Indonesia yang cerdas, terampil, dan berkarakter.

\section{Tujuan Pembelajaran PKn}

Setiap kegiatan belajar-mengajar, apapun materinya selalu memiliki sasaran (target). Sasaran yang juga lazim disebut tujuan itu pada umumnya tertulis. Akan tetapi, ada juga sasaran yang tak tertulis dan dikenal dengan objective in mind.

Sasaran yang dituju oleh kegiatan belajar mengajar bersifat bertahap dan meliputi beberapa jenjang yang konkret dan langsung dapat dilihat dan dirasakan sampai 
yang bersifat nasional dan universal. Ditinjau dari sudut waktu pencapaiannya, sasaran KBM dapat dikategorikan dalam tiga macam; (1) Sasaran-sasaran jangka pendek, seperti TPK (Tujuan Pembelajaran Khusus), (3) Sasaran-sasaran jangka menengah, seperti tujuan pendidikan dasar, yakni untuk mempersiapkan siswa mengikuti pendidikan menengah, (3) Sasaran jangka panjang, seperti tujuan pendidikan nasional.

Tujuan khas yang menjadi tanggung jawab guru sekolah adalah tujuan instruksional dan tujuan kurikuler. Sedangkan tujuan pedidikan secara nasional sebagaimana telah dijabarkan dalam undang -udang dan Peraturan menteri sebagai berikut:

\section{Undang-Undang Sistem}

Pendidikan Nasional No. 20 tahun 2003 Bab II pasal 3 tentang tujuan pendidikan nasional menyatakan:Pendidikan Nasional berfungsi mengermbangkan kemampuan dan membentuk watak serta peradaban bangsa yang bermartabat dalam rangka mencerdaskan kehidupan bangsa, bertujuan untuk berkembangnya potensi peserta didik agar menjadi manusia yang beriman dan bertakwa kepada Tuhan Yang Maha Esa, berakhlak mulia, sehat, berilmu, cakap, kreatif, mandiri, dan menjadi warga negara yang demokratis serta bertanggung jawab (Abd Razak ,2012:6).

Peraturan Pemerintah Republik Indonesia Nomor 19 Tahun 2005 Bab II Pasal 4 Tentang Standar Nasional Pendidikan menyatakan: Standar Nasional Pendidikan bertujuan menjamin mutu pendidikan nasional dalam rangka mencerdaskan kehidupan bangsa dan membentuk watak serta peradaban bangsa yang bermartabat.

\section{Pembelajaran Aktif}

Belajar aktif merupakan sebuah kesatuan sumber kumpulan strategi-strategi pembelajaran yang komprehensif. Belajar aktif meliputi berbagai cara untuk membuat peserta didik aktif sejak awal melalui aktivitas-akti vitas yang membangun kerja kelompok dan dalam waktu singkat membuat mereka berpikir tentang materi pelajaran. Juga terdapat teknik-teknik memimpin belajar bagi seluruh kelas, bagi kelompok kecil, merangsang diskusi dan debat, mempraktekkan keterampilan-keterampilan, mendorong adanya pertanyaan-pertanyaan, bahkan membuat peserta didik dapat saling mengajar satu sama lain.

Situasi di manapun dan kapanpun memberikan kesempatan belajar kepada seseorang. aktivitas - aktivitas belajar itu menurut Syaiful Bahri Djamarah meliputi: mendengarkan, memandang, meraba, membau, mencicipi/mengecap, menulis atau mencatat, membaca, membuat ikhtisar atau rangkuman dan menggarisbawahi, mengamati tabel-tabel, digram-diagram dan bagan-bagan, menyusun paper atau kertas kerja, mengingat, berpikir, serta latihan atau praktek (Syaifu Bahri Djamarah,2010;3).

\section{Metode Problem Solving}

Muhibbin Syah mendefinisikan metode diskusi sebagai berikut: Metode diskusi adalah metode mengajar yang sangat erat hubungannya dengan belajar memecahkan masalah (problem solving). Metode ini lazim juga disebut sebagai diskusi kelompok (group discussion) dan resitasi bersama (socialized recitation). Aplikasi metode problem solving biasanya melibatkan seluruh siswa atau sejumlah siswa tertentu yang diatur dalam bentuk kelompokkelompok( Muhibbin Syah 2009 120).

Menurut Masitoh, "Metode mengajar problem solving merupakan cara mengajar dalam pembahasan dan penyajian materinya melalui problema atau pertanyaan yang harus diselesaikan berdasarkan pendapat atau keputusan secara bersama( Masitih ;208. 120). Dan karakteristik dalam metode diskusi menurut Masitoh \& Laksmi Dewi adalah:1) Bahan pelajaran dengan topik permasalahan/persoalan. 2) Adanya pembentukan kelompok. 3) Ada yang mengatur pembicaraan., 4) aktivitas siswa berpendapat

Di dalam metode problem solving juga mengandung pengalaman belajar bagi siswa,1) Pemahaman terhadap persoalan, 2) Belajar bersama (cooperative learning), 3) Pemahaman pendapat orang lain, 4) Pembentukan rasa solidaritas, 5) Pemahaman terhadap pengambilan keputusan, 6) Menerapkan cara penyelesaian persoalan, 6) Menerapkan cara menyampaikan pendapat (Masitoh 2008 118).

Dari pemaparan di atas dapat ditarik 
kesimpulan bahwa keterlibatan siswa sebagai objek dan subjek dalam metode diskusi akan menjadikan mereka lebih percaya diri, termotivasi untuk mampu menuangkan gagasan, fleksibel dalam pergaulan, dan dapat mengendalikan diri, serta berpikir realistis, dan toleran.

Sedangkan kondisi dan kemampuan siswa yang harus diperhatikan untuk menunjang pelaksanaan problem solving diantaranya adalah: 1) Memiliki motivasi, perhatian, dan minat dalam berdiskusi, 3) Mampu melaksanakan diskusi, 4) Mampu belajar secara bersama, 5) Mampu mengeluarkan isi pikiran atau pendapat/ide,6) Mampu memahami pedapat orang lain.

Untuk terlaksananya dengan baik maka menjadi keharusan bagi guru sebagai pelaksana untuk mempersiapkan segala sesuatunya agar proses problem solving berjalan dengan dinamis dan antusias yang tinggi. Begitu pula bagi peserta, dalam hal ini para siswa, mereka pun harus mempersiapkan diri dengan segala kemampuan dan keterbatasannya untuk larut dan aktif di dalam perdebatan diskusi yang akan terjadi nantinya. Kelebihan/kekunggulan metode Problem Solving

Kelebihan metode Problem Solving menurut Syaiful Bahri Djamarah adalah: ( 1) Menyadarkan anak didik bahwa masalah dapat dipecahkan dengan berbagai jalan dan bukan satu jalan (satu jawaban saja), (2) Menyadarkan anak didik bahwa dengan problem solving mereka saling mengemukakan pendapat secara konstruktif sehingga dapat diperoleh keputusan yang lebih baik, (3) Membiasakan anak didik untuk mendengarkan pendapat orang lain sekalipun berbeda dengan pendapatnya sendiri dan membiasakan sikap toleran.

Adapun kekurangannya adalah:

(1) Tidak dapat dipakai pada kelompok yang besar, (2) Peserta diskusi mendapat informasi yang terbatas, (3) Dapat dikuasai oleh orangorang yang suka berbicara, (3) Biasanya orang menghendaki pendekatan yang lebih formal.

\section{METODE PENELITIAN}

Penelitian ini merupakan penelitian tindakan (action research), karena penelitian dilakukan untuk memecahkan masalah pembelajaran di kelas. Menurut Sukidin dkk. (2002:54) ada 4 macam bentuk penelitian tindakan, yaitu: (1) penelitian tindakan guru sebagai peneliti, (2) penelitian tindakan kolaboratif, (3) penelitian tindakan simultan terintegratif, dan (4) penelitian tindakan sosial eksperimental.

$$
\text { Penelitian ini mengacu pada }
$$

perbaikan pembelajaran yang berkesinambungan. Kemmis dan Taggart (1988:14) menyatakan bahwa model penelitian tindakan adalah berbentuk spiral. Tahapan penelitian tindakan pada suatu siklus meliputi perencanaan atau pelaksanaan observasi dan refleksi. Siklus ini berlanjut dan akan dihentikan jika sesuai dengan kebutuhan dan dirasa sudah cukup.

A. Tempat dan Waktu Penelitian

Penelitian ini dilaksanakan di SDN monyel semester satu tahun pelajaran 2017/2018 pada siswa kelas V I sebanyak 26 siswa yang terdiri dari 10 siswa laki-laki dan 16 siswa perempuan.

\section{Subyek Penelitian}

Sebagai subyek dalam penelitian ini adalah siswa kelas V I SDN monyel yang berjumlah 26 siswa yang terdiri dari 10 siswa laki - laki dan 16 siswa perempuan ,mereka memiliki latar belakang keluarga yang sebagian besar sebagai petani.

\section{Prosedur Penelitian}

Penelitian ini dilaksanakan melalui 4 tahap, yaitu, (1) tahap perencanaan, (2) tahap persiapan, dan (3) tahap pelaksanaan, (4) tahap pengolahan data.

\section{Desain Penelitian}

Sesuai dengan jenis penelitian yang dipilih, yaitu penelitian tindakan, maka penelitian ini menggunakan model penelitian tindakan dari Kemmis dan Taggart (2012:14), yaitu berbentuk spiral dari siklus yang satu ke siklus yang berikutnya. Setiap siklus meliputi planning (rencana), action (tindakan), observation (pengamatan), dan reflection (refleksi). Langkah pada siklus berikutnya adalah perncanaan yang sudah direvisi, tindakan, pengamatan, dan refleksi. Sebelum masuk pada siklus 1 dilakukan tindakan pendahuluan yang berupa identifikasi permasalahan. Siklus spiral dari tahap-tahap penelitian tindakan kelas dapat dilihat pada gambar berikut: 


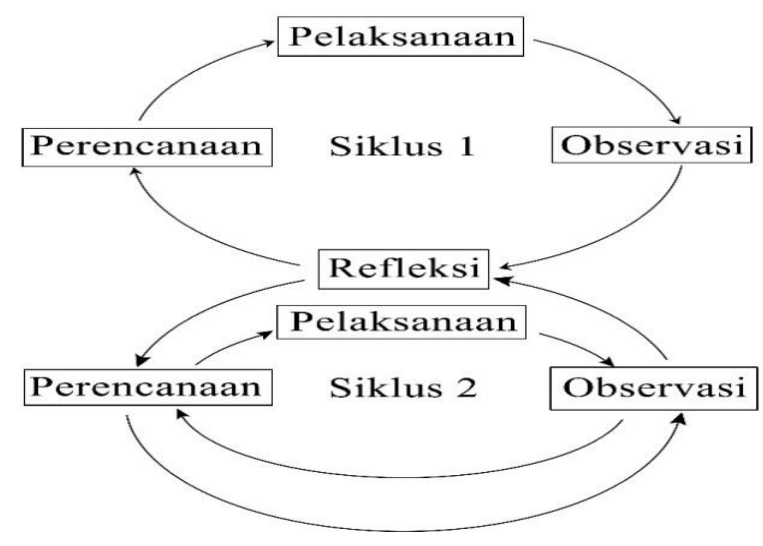

Penelitian ini dilaksanakan sebanyak dua siklus/putaran.Observasi dibagi dalam dua putaran, yaitu putaran 1, dan 2 , dimana masing putaran dikenai perlakuan yang sama (alur kegiatan yang sama) dan membahas satu sub pokok bahasan yang diakhiri dengan tes formatif di akhir masing putaran. Dibuat dalam dua putaran dimaksudkan untuk memperbaiki sistem pengajaran yang telah dilaksanakan.

\section{Teknik Analisis Data}

Untuk mengetahui keefektivan suatu metode dalam kegiatan pembelajaran perlu diadakan analisis data. Pada penelitian ini menggunakan teknik analisis dekriptif kualitatif ,untuk menganalisi tingkat keberhasilan atau peresentase keberhasilan siswa setelah proses belajar mengajar setiap siklusnya dilakukan dengan cara memberikan evaluasi berupa soal tes tertulis pada setiap akhir siklus . analisi ini dihitung dengan menggunakan statistik sederhana yaitu :

\section{Pengolahan data tes formatif}

Peneliti melakukan penjumlahan nilai yang diperoleh siswa, yang selanjutnya dibagi dengan jumlah siswa yang ada di kelas tersebut sehingga diperoleh rata-rata tes formatif dapat dirumuskan :

$$
\overline{\mathrm{X}}=\frac{\Sigma x}{\Sigma \mathrm{N}}
$$

Dengan $: \mathrm{X}=\overline{\text { Nilai rata-rata }}$

$$
\begin{aligned}
& \sum \mathrm{X}=\text { Jumla semua nilai siswa } \\
& \sum \mathrm{N} \quad=\text { Jumlah siswa }
\end{aligned}
$$

\section{Hasil Penelitian dan Pembahasan}

\section{Siklus I}

Tindakan penelitian diadakan pada bulan Agustus sampai dengan bulan November 2017 ,tindakan penelitian pada siklus I dilaksanakan pada hari Senin 21 Agustus dengan materi globalisasi di kelas VI jumlah peserta 26 orang ,dimana hasil anaalisis penilaian yang diperoleh sebagai berikut : dengan menerapkan Metode Problem Solving diperoleh nilai rata-rata hasil belajar siswa 68,84 dan ketuntasan belajar mencapai $57,69 \%$ atau ada 15 siswa dari 36 siswa sudah tuntas belajar, dan 11 orang siswa belum tuntas belajar atau persentase sebesar $42,30 \%$,jadi dengan demikian maka ketuntasan yang dikehendaki yaitu sebesar $85 \%$ belum tercapai. Hal ini disebabkan karena siswa masih merasa baru dan belum mengerti apa yang dimaksudkan dan digunakan guru dengan menerapkan pendekatan pembelajaran problem solving.

\section{Siklus II}

Pelaksanaan kegiatan belajar mengajar untuk siklus II dilaksanakan pada hari Jumat tanggal 28 September 2017 di kelas VI dengan jumlah siswa 26 siswa. Proses belajar mengajar mengacu pada Rencana Pelaksanaan Pembelajaran dengan memperhatikan revisi pada siklus pertama, sehingga kesalahan atau kekurangan pada siklus pertama tidak terulang lagi pada siklus dua .

Berdasarkan hasil tes formatif pada siklus 2 adalah sebagai berikut: nilai rata-rata hasil belajar siswa 90,38 dan ketuntasan belajar mencapai 92,30 \% atau 24 siswa dari 26 siswa sudah tuntas belajar, dan 2 siswa belum tuntas belajar atau persentase sebesar 7,69 \% ,jadi dengan demikian maka ketuntasan yang dikehendaki yaitu sebesar $85 \%$ sudah tercapai. Hal ini disebabkan karena guru mampu mengatasi kendala yang yang terjadi pada siklus I ,maka dengan demikian penelitian dihentikan sampai pada siklus II.

\section{Pembahasan Hasil Penelitian}

Dengan mencermati hasil penelitian ini menunjukkan bahwa Metode Problem solving memiliki dampak positif dalam meningkatkan hasil belajar siswa. Hal ini dapat dilihat dari semakin mantapnya pemahaman siswa terhadap materi yang disampaikan guru ,data hasil belajar siswa pada siklus I dengan menerapkan Metode Problem Solving diperoleh nilai rata-rata hasil belajar siswa 68,84 dan ketuntasan belajar mencapai 57,69 \% atau ada 15 siswa dari 36 siswa sudah tuntas belajar. Dan 11 orang siswa belum tuntas belajar atau 
persentase sebesar $42,30 \%$,jadi dengan demikian maka ketuntasan yang dikehendaki yaitu sebesar $85 \%$ belum tercapai. Hal ini disebabkan karena siswa masih merasa baru dan belum mengerti apa yang dimaksudkan dan digunakan guru dengan menerapkan pendekatan pembelajaran problem solving.

Data hasil belajar siswa pada siklus II sebagai berikut dengan menerapkan Metode Problem Solving diperoleh nilai ratarata hasil belajar siswa 90,38 dan ketuntasan belajar mencapai $92,30 \%$ atau 24 siswa dari 26 siswa sudah tuntas belajar, dan 2 siswa belum tuntas belajar atau persentase sebesar $7,69 \%$,jadi dengan demikian maka ketuntasan yang dikehendaki yaitu sebesar $85 \%$ sudah tercapai. Hal ini disebabkan karena guru mampu mengatasi kendala yang yang terjadi pada siklus I ,maka dengan demikian penelitian dihentikan sampai pada siklus II.

Dari ke dua data tersebut diatas terjadi peningatan hasil yang cukup signifikan dimana pada siklus I diperoleh nilai rata - rata sebesar 64,84 meningkat pada siklus II sebesar 90,38 terjadi peningatan 21,54 poin sementara porsentase ketuntasan pada siklus I sebesar 57,69 \% meningkat pada siklus II menjadi 92,30 terjadi peningkatan sebesar 34,61 poin, jadi dengan demikian maka ketuntasan yang dikehendaki yaitu sebesar $\geq$ 85 sudah tercapai maka dengan demikian penelitian dihentikan sampai pada siklus II.

\section{KESIMPULAN}

Mata Pelajaran PKn perlu diajaran dengan metode-metode dan teknik yang sesuai dengan perkembangan dan kebutuhan peserta didik, bukan saja menjejalkan dengan ilmu pengetahuan tetapi juga dengan nilainilai luhur budaya bangsa yang kini mulai tergerus, rasa kedisiplinan yang semakin merosot, sehingga berimbas pada hasil belajar. Dengan menggunakan metode Problem solving terjadi peningatan hasil yang cukup signifikan dimana pada siklus I diperoleh nilai rata - rata sebesar 64,84 meningkat pada siklus II sebesar 90,38 terjadi peningatan 21,54 poin sementara porsentase ketuntasan pada siklus I sebesar 57,69\% meningkat pada siklus II menjadi 92,30 terjadi peningkatan sebesar 34,61 poin , jadi dengan demikian maka ketuntasan yang dikehendaki yaitu sebesar $\geq 85$ sudah tercapai maka dengan demikian penelitian dihentikan sampai pada siklus II.

\section{DAFTAR PUSTAKA}

Arifin, Zaenal. Evaluasi Pembelajaran. Bandung: Reja Rosdakarya, Cet. I, 2009.

Arikunto, Suharsimi., Suhardjono., dan Supardi. Penelitian Tidakan Kelas. Jakarta: Bumi Aksara, Cet. IX, 2009.

Budimansyah, Dasim., dan Karim Suryadi. PKn dan Masyarakat Multikultural.

Bandung: UPI, Cet. I, 2008.

Djamarah, Syaiful Bahri. Psikologi Belajar. Jakarta: Rineka Cipta, Cet. II, 2008.

---------, Guru dan Anak Didik dalam Interaksi Edukatif. Jakarta: Rineka Cipta, Cet. I, 2000.

Engkoswara. Dasar-Dasar Metodologi Pengajaran.. Jakarta: Bina Aksara, Cet. I, 1984.

Fatra, Maifalinda., Abd. Rozak. Penelitian Tindakan Kelas. Jakarta: FITK UIN Jakarta, 2010.

Hamalik, Oemar. Dasar-Dasar Pengembangan Kurikulum. Bandung: Remaja Rosdakarya, Cet. III, 2009.

Hermawan, Heris A. Filsafat Pendidikan Islam. Jakarta: Direktorat Pendidikan Islam Departemen Agama Republik Indonesia, 2009.

Hufad, Achmad. Penelitian Tindakan Kelas. Jakarta: Direktorat Pendidikan Islam Departemen Agama Republik Indonesia, 2009.

Kalidjernih, K, Freddy. Puspa Ragam (Konsep dan Isu Kewarganegaraan. Widya Aksara Press, Ed. II, 2010.

Majid, Abdul. Perencanaan Pembelajaran. Bandung: Remaja Rosdakarya, Cet. V I, 2011.

Masitoh dan Laksmi Dewi. Strategi Pembelajaran. Jakarta: Direktorat Pendidikan Islam Departemen Agama Republik Indonesia, 2009.

Riduwan. Belajar Mudah Penelitian Untuk Guru, Karyawan, dan Peneliti Pemula. Bandung: Alfabeta, Cet. III, 2006.

Rozak, Abd., Fauzan., dan Ali Nurdin. Kompilasi Undang-Undang dan Peraturan Bidang Pendidikan. Jakarta: FITK Press, 2010. 